\title{
Growth and Yield Production of Canola as Affected by Organic and Mineral Fertilizers Application under Drought Stress Conditions
}

\author{
Saied El Sayed ${ }^{1^{*}}$, Farid Hellal $^{1}$ and Hanan H. Abdel-Kader ${ }^{1}$ \\ ${ }^{1}$ Plant Nutrition Department, National Research Centre, El-Behouth St., 12622, Dokki, Cairo, Egypt.
}

\section{Authors' contributions}

This work was carried out in collaboration among all authors. Author SES designed the study, performed the statistical analysis, wrote the protocol and wrote the first draft of the manuscript. Authors FH and HHAK managed the analyses of the study and the literature searches. All authors read and approved the final manuscript.

Article Information

DOI: $10.9734 / A R R B / 2021 / v 36 i 130328$ Editor(s):

(1) Dr. Rishee K. Kalaria, Navsari Agricultural University, India.
Reviewers:

(1) José Augusto Dos Santos Neto, UNIMONTES, Brazil. (2) Mohamed Ali Abdelsatar, Agricultural Research Center, Egypt. Complete Peer review History: http://www.sdiarticle4.com/review-history/64728

Original Research Article

Received 20 November 2020

Accepted 13 January 2021

Published 14 January 2021

\begin{abstract}
Field experiment were carried out at the Research and Production Station of the National Research Centre, Nubaria region, Behiera Governorate, Egypt during 2019/2020 to study the effects of compost and zinc foliar application on growth and yield production of canola under drought condition. The water stress treatments (75 and $40 \%$ water holding capacity, WHC) occupied the main plots and compost treatments at the rates (0,2, 4 and 6 ton fed-1) were allocated at random in the sub-plots with the foliar application of zinc at a rate of 0,50 and 100 ppm. Data noticed that increase compost rate associated with increasing the SPAD red and RWC under both irrigation treatments where $75 \% \mathrm{WHC}$ scored the highest values than $40 \% \mathrm{WHC}$. Results indicated that increasing compost rates was associated with increasing of canola characters plant height, number of branch, number of pods and 1000 seeds weight as well as, seed yield, biological yield as affected by compost and zinc application rates and their interaction under normal and stress treatments. Also, data illustrated that stress tolerance indices (SSI, STI, GMP, YI, YSI, MP, TOL and HM) of canola as affected by water stress and Compost application and Zinc sulphate. Data indicated that the highest values were attained after application compost
\end{abstract}


at a rate of 6.0 ton fed-1 with a foliar spray $\mathrm{ZnSO} 4$ at a rate of $100 \mathrm{ppm}$. Results concluded that, application of compost and zinc is important for enhancing the growth parameter and seed production of canola under water stress condition.

Keywords: Canola; drought; treatment, fertilizer; foliar application.

\section{INTRODUCTION}

Canola (Brassica napus L.) has been an important crop for many decades, Canola is one of the most important oilseed plants that have high compatibility in resistance to drought and salinity stresses. After soybean, the largest cultivation area of oilseed plants is accounted to canola, and in terms of oil providing, after soybean and oil palm it is in third place [1]. Like many of the oilseed plants, canola is effected stress caused by the water deficits. Studies have shown that the incidence of water deficit at different growth stages, especially reproductive growth, is the effect of quantity and quality of oil [2].

Abiotic stresses like water stress may lead to changes in oil content and compositions in plants [3], a result of water shorting condition frequently alters the composition and biosynthesis process of fatty acids leading to the reduction of oil yield and composition [4]. While, Amini [5] found a remarkable effect of water shortage stress on seed quality (specialy of protein) of oilseed crops.

The use of fertilizers and manure is important to enhance soil fertility and crop yield improvement [6]. Application of manure in the soil, increased water holding capacity in soil, water use efficiency besides increasing soil fertility and crop growth [7]. The compost application into soil improved seed germination and the dry matter yield as compared to control treatments [8]. The application of compost combined with chemical fertilizers in the field enhance the ability to access the elements uptake and can be increased the yield production ability and soil fertility [9]. The compost application increased microbial activity, nitrogen concentration and grain yield [10].

Zinc $(\mathrm{Zn})$ is one of the essential microelements required for plant growth since it is an important component in the carbonic anhydrase enzyme which is present in all photosynthetic tissues, and required also for chlorophyll biosynthesis $[11,12]$. It involved in many physiological functions, protein and carbohydrate synthesis [13]. The Zn application under water stress conditions could influence the crop yield and quality. Zinc sulfate has an important role in the plant system to decrease water stress, leading to the inaccessibility of $\mathrm{Zn}$ uptake by plant [14]. The objectives of present study the effects of organic compost addition to the soil and micronutrient such as of zinc foliar application on grown, nutrient content, chemical constitute of canola plant under water stress conditions.

\section{MATERIALS AND METHODS}

\subsection{Experimental Procedures}

Field experiment were carried out at the Research and Production Station of the National Research Centre, Nubaria region (30 30.054' N 30 19.421' E), Behiera Governorate, Egypt during 2019/2020. Seeds of Canola (Brassica napus L.) cv. Sarw were sown on November in season. The experimental design was a split plot with four replications. The Water stress treatments (75 and $40 \%$ water holding capacity, WHC) occupied the main plots and compost treatments at the rates $\left(0,2,4\right.$ and 6 ton fed $\left.^{-1}\right)$ were allocated at random in the sub-plots with the foliar application of zinc at a rate of 0,50 and $100 \mathrm{ppm}$. The plot area was $9 \mathrm{~m}^{2}$. Some physical and chemical properties of a representative soil sample used of the experimental site were determined before sowing according to [15] and presented in (Table 1).

Calcium super-phosphate $\left(\begin{array}{llll}15.50 \% & \left.\mathrm{P}_{2} \mathrm{O}_{5}\right) & \text { was }\end{array}\right.$ added pre-sowing at $150 \mathrm{Kg} / \mathrm{fed}$ (ha=2.4 fed, $\mathrm{fed}=\mathrm{feddan}$ ) to the soil; similarly, nitrogen in the form of ammonium nitrate $(33.0 \% \mathrm{~N})$ at the rate of $20 \mathrm{~kg} \mathrm{~N} / \mathrm{fed}$ as starter dose was added before first irrigation, Potassium sulphate $\left(48 \% \quad \mathrm{~K}_{2} \mathrm{O}\right)$ was added at the rate of $50 \mathrm{~kg} / \mathrm{fed}$ to the soil in two equal doses at 21 and 35 days after sowing. Canola plants were irrigated and maintained during the whole growth season using drip irrigation system. Foliar spray of Zinc sulphate was applied three doses to canola plants during the growth stage. The interaction of different concentrations of both compounds was also assessed in addition to untreated plants (control). Table 2 shows the components of a representative compost sample used of the experimental site. 
Table 1. Some physical and chemical properties of the experimental soil

\begin{tabular}{|c|c|c|c|c|c|c|c|}
\hline \multirow{2}{*}{$\begin{array}{l}\text { pH } \\
(1: 2.5)\end{array}$} & \multirow{2}{*}{$\begin{array}{l}\text { EC } \\
d^{-1} m^{-1}\end{array}$} & \multirow{2}{*}{$\begin{array}{l}\mathrm{OM} \\
\%\end{array}$} & \multirow{2}{*}{$\begin{array}{l}\mathrm{CaCO}_{3} \\
\%\end{array}$} & \multicolumn{3}{|c|}{ Particle size distribution } & \multirow{2}{*}{\begin{tabular}{|l|} 
Texture \\
Class
\end{tabular}} \\
\hline & & & & Sand \% & Silt \% & Clay \% & \\
\hline 7.76 & 1.26 & 0.84 & 2.98 & 75.7 & 5.3 & 18.28 & Sandy loam \\
\hline \multicolumn{4}{|c|}{ Cations (mg / 100 g soil) } & \multicolumn{4}{|c|}{ Anion (mg / 100 g soil) } \\
\hline $\begin{array}{l}\mathrm{Na}^{+} \\
3.62\end{array}$ & $\begin{array}{l}\mathrm{K}^{+} \\
1.41\end{array}$ & $\begin{array}{l}\mathrm{Ca}^{++} \\
3.52\end{array}$ & $\begin{array}{l}\mathrm{Mg}^{+} \\
1.48\end{array}$ & $\begin{array}{l}\mathrm{CO}_{3} \\
0.38\end{array}$ & $\begin{array}{l}\mathrm{HCO}_{3} \\
3.81\end{array}$ & $\begin{array}{l}\mathrm{Cl}^{-} \\
1.82\end{array}$ & $\begin{array}{l}\mathrm{SO}_{4}^{--} \\
3.44\end{array}$ \\
\hline \multicolumn{4}{|c|}{ Available macronutrients (mg/100 g soil) } & \multicolumn{4}{|c|}{ Available micronutrients (mg/kg) } \\
\hline $\begin{array}{l}\mathrm{N} \\
15.33\end{array}$ & & $\begin{array}{l}P \\
3.98\end{array}$ & & $\begin{array}{l}\mathrm{Fe} \\
11.61\end{array}$ & $\begin{array}{l}\mathrm{Zn} \\
0.09\end{array}$ & $\begin{array}{l}M n \\
5.89\end{array}$ & $\begin{array}{l}\mathrm{Cu} \\
0.011\end{array}$ \\
\hline
\end{tabular}

Table 2. Compost manure analysis parameters

\begin{tabular}{llllllll}
\hline pH & EC & Organic & Organic & C/N & \multicolumn{3}{c}{ Macronutrient (\%) } \\
\hline $\mathbf{( 1 : 5 )}$ & $\mathbf{( 1 : 5 )}$ & Matter \% & Carbon \% & ratio & $\mathbf{N}$ & $\mathbf{P}$ & $\mathbf{K}$ \\
\hline 7.72 & 2.53 & 25.13 & 14.81 & 23.51 & 0.63 & 0.273 & 0.34 \\
\hline
\end{tabular}

Some biochemical aspects were determined including photosynthetic pigments in fresh leaves using the method of SPAD according to [16]. Proline content was extracted and calculated according to [17]. Leaf relative water content (RWC) was estimated according to $[18,19]$ for each drought period.

\subsubsection{Biological yield}

The total biomass of the harvested plants $(\mathrm{kg}$ plot $^{-1}$ ), then it was transformed into ton per feddan.

\subsubsection{Grain yield (ton $\mathrm{ha}^{-1}$ )}

It was obtained as the weight of clean grains of the plot after threshing, and then it was transformed into tone per feddan.

\subsubsection{Harvest index}

Harvest index (H.I) calculated as follows:

$$
\text { H. I. }=\frac{\text { Grain yield (ton } / \text { fed) }}{\text { Biological yield (ton } / \text { fed) }} \times 100
$$

\subsubsection{Drought tolerance indices}

Five drought tolerance indices including stress susceptibility index (SSI), tolerance index (TOL), mean productivity (MP), geometric mean productivity (GMP) and stress tolerance index (STI). The relative decrease in yield were calculated based on grain yield under drought (Ys) and irrigated (Yp) conditions. Drought tolerance indices were calculated by using the equations cited in Table 3.
$\hat{Y} s$ and $\hat{Y} p$ are mean grain yield of all genotypes in stress and non-stress conditions. SSI: The genotypes with $\mathrm{SSI}<1$ are more resistant to drought stress condition, TOL: The genotypes with low values are more stable in two different condition, MP: The genotypes with high values will be more desirable, GMP: The genotypes with high values will be more desirable, STI: The genotypes with high values will be tolerant to drought stress.

\subsection{Statistical Analysis}

A combined analysis of data for the two seasons were statistically analyzed according to the technique of analysis of variance (ANOVA) for the split-plot design using [25] computer software package. Least Significant Difference (LSD) method was used to test the differences among treatment means at $5 \%$ level of probability as described by [26].

\section{RESULTS AND DISCUSSION}

\subsection{Photosynthetic Pigments And Relative Water Content (Rwc) Of Leaves}

Data in Table 4 showed the effect of both factors under study (compost and $\mathrm{ZnSO}_{4}$ ) on the SPAD red and RWC under sufficient and deficit irrigation. The obtained results indicated that the lowest values of the studied two factors were observed at control. While the highest ones recorded were $12.94,5.47$ and $17.45,3.33 \%$ as affected by application compost at a rate of 4.0 ton fed $^{-1}$ with Zinc at a rate of 100 as compared with control, respectively. While, data observed 
that from application at a rate of 6.0 ton $^{-1} \mathrm{ded}^{-1}$ were $12.82,7.29 \%$ and $24.45,6.29 \%$ comparing 6.0 ton fed $^{-1}$ compost with control, respectively. Physical properties such as, the use of fertilizers along with chemical fertilizers has significantly improved bulk density, porosity, water permeability and hydraulic conductivity [27].

According to the influence of the compost application rate on the SPAD red and RWC, data noticed that increase compost rate associated with increasing the SPAD red and RWC under both irrigation treatments where $75 \% \mathrm{WHC}$ scored the highest values than $40 \% \mathrm{WHC}$. There must be effective equilibrium during periods of water deficit that, applies to the use of zinc sulfate which plays a more important role than other fertilizers in stomata regulation and maintaining the balance of ions in plant systems to reduce drag stress [28].

With respect to the effect of compost on chlorophyll and relative water content in plant, data showed that 4.0 ton $\mathrm{fed}^{-1}$ of compost recorded values with increase in percentage 14.90 and $4.48 \%$ as compared with control, respectively. While, 6.0 ton $^{-1} \mathrm{fed}^{-1}$ of compost recorded the highest values with increase in percentage 17.86 and $6.83 \%$ relative to control, respectively. Same trend was observe it in case of zinc application rates where $100 \mathrm{ppm}$ caused an increase of micronutrients content in canola plant by about 14.97 and $9.91 \%$ in same previous sequence. These results were consistent with previous results [29]. Zinc is essential for the biosynthesis of chlorophyll, as it is a component of the carbonic anhydrase enzyme present in photosynthesis tissues, making it one of the essential micronutrients required for crop growth [11]. Tariq [30] reported that foliar application of micro-nutrients improves crop quality and increases resistance in plants against biotic and abiotic stresses.

With respect to the proline content, data of the mean values of the compost application rate effect, increase compost rate a combined with a reduction estimated by percentage relative to the control by about $7.15 ; 3.07$ and $14.20 ; 10.74 \%$ for $4 ; 6$ ton compost fed ${ }^{-1}$ under sufficient and deficit irrigation treatments, respectively. The obtained results indicated that the lowest values of the studied two factors were 4.83 and $12.24 \%$ as affected by application compost at a rate of 4.0 and 6.0 ton fed $^{-1}$ as compared with control, respectively. Also, Data showed that application of zinc at a rate of $100 \mathrm{ppm}$ reduction of proline content under sufficient and deficit irrigation at about $21.42 \%$ compared to control. These agreed with the results observed by [31].

\subsubsection{Growth parameters}

Data infested in Table 5 and Fig. $1 \mathrm{a} \& 1 \mathrm{~b}$ showed some canola characters plant height $(\mathrm{cm})$, number of branch per plant, number of pods per plant and 1000 seeds weight as affected by compost and zinc application rates and their interaction under normal and stress treatments. Resulted data noticed that values of the studied canola plant characters were more than under Normal irrigation $(\mathrm{NI})$ than water stress. While control treatment of zinc $(0 \mathrm{ppm})$ under all compost application rates gained the lowest values with respect to lowest values that attained at control of compost plus zinc treatments.

Whereas, the highest values of the studied canola plant characters were observe after 100 ppm application rate and 6 ton compost. With respect to the highest ones were observed at 6 ton compost and $100 \mathrm{ppm}$ zinc. Compost is particularly effective when added with fertilizer at the time of planting. Not only do seeds germinate faster when compost is present, but a higher percentage of seeds germinate. Compost becomes a source of phosphate and carbon by stimulating micro flora populations [32].

Some studies have found that plant height in wheat is affected by stress, while with zinc added significantly increased the plant height [33]. Same previous trend was observed in case of compost effect on the selected canola characters where increasing compost rates was associated with increasing of canola plant characters wither under normal irrigation and water stress treatments. The reduction resulted from stress ranged from 14.8-23.3, 13.0-19.7, 24.6-27.1 and $22.0-25.2 \%$ after $6-0,0-6,0-2$ and $2-6$ ton compost for studied canola characters (plant height $(\mathrm{cm})$, number of branch per plant, number of pods per plant and 1000 seeds weight). Also, data noticed that the rate of increase in examined canola characters were $3.11,10.19$, $3.39 ; \quad 2.39 \%$ and $11.47,2.69,4.78 ; 3.59$ comparing 4.0 ton fed ${ }^{-1}$ compost with the control, respectively. While, increase in examined canola characters were $4.12,20.15,7.97 ; 4.57 \%$ and $11.73,8.39,6.77 ; 6.96 \%$ comparing 6 ton compost with control, respectively. The use of compost will not only supplement the chemical fertilizers, but also reduce environmental 
pollution. In this strategy, the production cost is also reduced. Thus, a higher yield with higher incomes resultantly is expected by the farming community in this culture system [34].

According to the zinc application rates effect on canola plant characters (plant height $(\mathrm{cm})$, number of branch per plant, number of pods per plant and 1000 seeds weight) under both irrigation treatments, data noticed that the increase zinc combined with increase of the examined canola plant characters. Also, data infested in table that maximum and minimum values were recorded at 0 and $100 \mathrm{ppm}$ under both irrigation treatments, where the values under Normal irrigation were more than that under stress. Using compost in sustainable agriculture manner preserves agro-ecosystems and environmental quality [35].

Regardless irrigation treatments, data in Table 5 showed the effect of both compost and zinc application rates and their interactions on the canola plant characters. Data on hand revealed that untreated treatment with zinc under all compost treatments gained the lowest values while, $100 \mathrm{ppm}$ zinc and 6 ton compost scored the highest values. Zinc sulfate spraying had also a significant impact on the increase of the number of branch per plant and number of pods per plant, in a way that spraying with a concentration of $100 \mathrm{ppm}$ (Table 5) these results harmony with [36].

It also indicates the positive effect of fertilizers containing micronutrients such as zinc sulfate on the number of sunflower seeds. Moreover, some reports have been presented on the positive role of using zinc sulfate fertilizer in the number of seeds produced in wheat and canola crops.

With respect to the effect of compost on plant characters, data showed that application of 4.0 ton fed ${ }^{-1}$ scored values with increase in percentage $6.87,6.63,3.99 ; 2.92$ compared with the control, respectively. Also, application of 6.0 ton fed $^{-1}$ of compost scored the highest values with increase in percentage 15.9, 37.1, 32.3, 19.8 relative to control, respectively. Same trend was observe it in case of zinc application rates where $100 \mathrm{ppm}$ caused an increase in canola plant characters by about 13.10, 32.4, 21.5 and $10.73 \%$ in same previous sequence. Movahedy Dehnavy [37] showed that Zn spraying to a degree compensated the spoilage to safflower plants caused by the water stress. As well as, yield components including head number/plant, grain number/head and 1000-grain weight were improved by $\mathrm{Zn}$ spraying at flowering and pollination stages.

\subsubsection{Yield production}

Data in Table 6 Fig. $2 a$ \& $2 b$ represented the effect of compost and zinc application rate and their interactions under normal and water stress treatment on the values of biomass, seed yield, biological yield and harvest index of canola plant characters. The obtained result revealed that control of compost and zinc application rates gained the lowest values of under Normal and water stress treatments except for harvest index where 0 compost plus $50 \mathrm{ppm}$ zinc under normal condition with 6 ton compost +100 ppm zinc scored the highest values of (biomass, seed yield, biological yield and harvest index) except for harvest index where 6 ton compost +0 zinc scored the highest values under both irrigation treatments.

In many crops, garden and pasture the compost application has been reported positive [38]. The addition of compost increased bacterial activity, nitrogen concentration and grain yield [10]. These organic sources have a profound effect on crop yield and quality [39]. In organic farming compost, compost and extracts are used to improve soil fertility and control pests and diseases [40].

Regarding to the effect off compost application rates on the canola yield characters (biomass, seed yield, biological yield and harvest index) under irrigation treatments, data on hand pointed out that the increase of compost rate associated with increase of the studied canola yield characters under both rogation treatments. The minimum and maximum values of studied canola yield characters were observed at control of compost ( 0 ton) and 6 ton, respectively. It is clear to mention that the highest reduction resulted from water stress were found at 2, 4, 6 ton for studied canola yield characters, respectively. About that, Observed from data application of 4.0 ton fed ${ }^{-1}$ compost increased the values of studied canola yield characters by about 2.71, 28.11, 9.46;17.22\% and $2.84,10.73,4.93 ; 5.55 \%$ under sufficient and deficit irrigation treatments, prospectively. While, 6.0 ton $\mathrm{fed}^{-1}$ compost increased the relative values of studied canola yield characters by about $4.34,29.37,11.00,16.75 \%$ and 5.14 , $16.75,8.21 ; 7.88 \%$ under normal and water stress irrigation treatments, prospectively. 
Table 3. Stress tolerance indices used for the evaluation of barley genotypes to drought tolerance

\begin{tabular}{lll}
\hline Stress tolerance indices & Equation & Reference \\
\hline Stress susceptibility index & $\mathrm{SSI}=1-(\mathrm{Ys} / \mathrm{Yp}) / 1-(\hat{\mathrm{Y} s} / \hat{\mathrm{Y} p})$ & {$[20]$} \\
Mean productivity & $\mathrm{MP}=(\mathrm{Ys}+\mathrm{Yp}) / 2$ & {$[21]$} \\
Stress tolerance & $\mathrm{TOL}=\mathrm{Yp}-\mathrm{Ys}$ & {$[21]$} \\
Geometric mean productivity & $\mathrm{GMP}=\left(\mathrm{Yp}{ }^{*} \mathrm{Ys}\right) 1 / 2$ & {$[22]$} \\
Stress tolerance index & $\mathrm{STI}=\left(\mathrm{Yp}{ }^{*} \mathrm{Ys}\right) /(\hat{\mathrm{Y} p}) 2$ & {$[22]$} \\
Yield index & $\mathrm{YI}=\mathrm{Ys} / \hat{\mathrm{Y} s}$ & {$[23]$} \\
Yield stability index & $\mathrm{YSI}=\mathrm{Ys} / \mathrm{Yp}$ & {$[24]$} \\
\hline
\end{tabular}

Table 4. SPAD-chlorophyll, RWC and proline content of canola plant as affected by compost and zinc sulfate application

\begin{tabular}{llllllll}
\hline Compost & \multirow{2}{*}{ Zn levels } & \multicolumn{2}{c}{ Chlorophyll } & \multicolumn{3}{c}{ RWC $^{*}$} & \multicolumn{2}{c}{ Proline (mg gf.w ${ }^{-1}$ ) } \\
\cline { 3 - 7 } & & Normal & Stress & Normal & Stress & Normal & Stress \\
\hline 0 & No Zn applied & 47.65 & 32.64 & 81.9 & 65.9 & 0.427 & 0.567 \\
ton/fed & Zn 50 ppm & 48.19 & 37.44 & 83.5 & 72.6 & 0.408 & 0.468 \\
& Zn 100 ppm & 49.90 & 41.56 & 85.4 & 76.8 & 0.327 & 0.346 \\
\hline (2) & No Zn applied & 45.80 & 29.08 & 77.7 & 64.8 & 0.433 & 0.633 \\
ton/fed & Zn 50 ppm & 46.30 & 32.12 & 81.3 & 71.5 & 0.413 & 0.513 \\
& Zn 100 ppm & 47.86 & 38.76 & 83.6 & 75.2 & 0.380 & 0.429 \\
\hline (4) & No Zn applied & 50.95 & 39.40 & 86.2 & 70.7 & 0.337 & 0.437 \\
ton/fed & Zn 50 ppm & 55.15 & 42.84 & 87.5 & 72.2 & 0.308 & 0.361 \\
& Zn 100 ppm & 58.50 & 48.88 & 90.8 & 79.6 & 0.229 & 0.245 \\
\hline (6) & No Zn applied & 53.81 & 41.98 & 88.4 & 71.6 & 0.314 & 0.385 \\
ton/fed & Zn 50 ppm & 54.65 & 45.96 & 89.2 & 74.6 & 0.251 & 0.286 \\
& Zn 100 ppm & 55.96 & 51.00 & 91.5 & 82.6 & 0.197 & 0.202 \\
\hline Mean of & No compost & 48.58 & 37.21 & 83.60 & 71.75 & 0.39 & 0.46 \\
Compost & 2 ton/fed & 46.65 & 33.32 & 80.90 & 70.51 & 0.41 & 0.53 \\
& 4 ton/fed & 54.87 & 43.71 & 88.17 & 74.15 & 0.29 & 0.35 \\
& 6 ton/fed & 54.81 & 46.31 & 89.69 & 76.27 & 0.25 & 0.29 \\
\hline Mean of & No Zn applied & 49.6 & 35.8 & 83.5 & 68.2 & 0.378 & 0.506 \\
Zn & Zn 50 ppm & 51.1 & 39.6 & 85.4 & 72.7 & 0.345 & 0.407 \\
& Zn 100 ppm & 53.1 & 45.1 & 87.8 & 78.5 & 0.284 & 0.305 \\
\hline LSD & Compost (Co) & 0.95 & 1.20 & 0.69 & 0.81 & 0.011 & 0.011 \\
0.05 & Zinc (Zn) & 0.82 & 1.04 & 0.75 & 1.23 & 0.007 & 0.008 \\
& (Co*Zn) & 1.65 & 2.07 & 1.34 & 1.89 & 0.017 & 0.017 \\
\hline & & & $(R W C) ;$ Relative Water Content & &
\end{tabular}

The use of compost improves seed germination and dry matter production compared to the compost free treatments [8]. Increase in biological yield might be to due increased grain yield. It may be due to the activation of various physiological processes such as regulation of the mouth, formation of chlorophyll, enzyme activation, and biochemical processes through the use of micronutrients that led to the production of high dry matter [41].

Regardless irrigation treatments, data in Table 6, Fig. $2 a \quad \& 2 b$ indicated that control of compost and zinc gained the lowest values except harvest index where $100 \mathrm{ppm}$ of zinc and 6 ton compost+100 ppm zinc scored the highest values except harvest index (after 0 Zinc). Foliar application of zinc and irrigation levels significantly affected the biological yield and grain yield (ton ha ${ }^{-1}$ ): Foliar application of $\mathrm{Zn}$ at different concentrations and irrigation levels significantly affected grain yield.

Interaction between these two factors also found to be significant. In foliar applications of zinc at different concentrations, foliar applied zinc at 100 ppm considerably increased grain yield. These results are inconformity with the findings of [41], [42], who reported that foliar application of zinc significantly increases the yield and yield 
contributing parameters. As well as, the positive effect of compost on increasing canola yield may be rendered to the role of compost on reducing $\mathrm{PH}$ of the soil. With respect to the effect of compost application rates on the studied canola yield characters (biomass, seed yield, biological yield and harvest index), data indicated that maximum and the minimum values were 2.76 , $20.69,7.51$ and $11.39 \%$ recorded by application of compost at a rate of 4.0 ton fed ${ }^{-1}$, respectively. While, 6.0 ton fed ${ }^{-1}$ recorded of increase at about $4.69,23.95,9.80,12.32 \%$, prospectively. Regarding to zinc application rates and it's effect on studied canola yield characters, data revealed that increased zinc application rate led to increase in the studied canola yield characters, where the opposite was true and the improvement in the studied canola yield characters estimated in percentage were 6.07, $8.09,6.63$ and $1.55 \%$, respectively. Using compost in sustainable agriculture manner preserves agro-ecosystems and environmental quality [35]. It is a key ingredient in organic farming and is one of nature's best mulches and soil amendments, and can be used instead of commercial fertilizers. It also improves soil structure and aeration and increases the waterholding capacity of soil [43].

\subsection{Stress Tolerance Indices}

Data in Table 7 illustrated that stress tolerance indices (SSI, STI, GMP, YI, YSI, MP, TOL and $\mathrm{HM}$ ) of canola as affected by water stress and Compost application and Zinc sulphate $\left(\mathrm{ZnSO}_{4}\right)$. Data indicated that the highest values were attained after application of compost at rates of 4.0 and 6.0 ton fed ${ }^{-1}$ with a foliar spray $\mathrm{ZnSO}_{4}$ in most stress tolerance indices. Resulted data showed that the highest values were 1.17, 0.89, 1.14, 1.11, 1.08, 0.48 and 1.09 (SSI, STI, GMP, YI, MP, TOL and HM), respectively. While, achieved data the lowest values with YSI were 0.53 as affected by application compost at a rate 4.0 ton fed $^{-1}$ with the foliar spray Zinc sulphate at a rate of $100 \mathrm{ppm}$ compared to control. Also, Data observed in Table 7 were 1.099, 0.728, $1.06,1.01,1.08,0.64$ and 0.96 (SSI, STI, GMP, YI, MP, TOL and HM), respectively.

Table 5. Plant height, no. of branch, no. of pods /plant and 1000 seed wt. of canola plant as affected by compost and zinc sulfate application

\begin{tabular}{llllllllll}
\hline Compost Zn Levels & \multicolumn{2}{c}{$\begin{array}{c}\text { Plant height } \\
\text { (cm) }\end{array}$} & \multicolumn{2}{c}{$\begin{array}{c}\text { No. of } \\
\text { Branch }\end{array}$} & \multicolumn{2}{c}{$\begin{array}{c}\text { No. of Pods } \\
\text { /plant }\end{array}$} & \multicolumn{2}{c}{$\begin{array}{c}\text { 1000 seed wt. } \\
\text { (g) }\end{array}$} \\
\cline { 3 - 10 } & & Normal & Stress & Normal & Stress & Normal & Stress & Normal & Stress \\
\hline 0 & No Zn & 113.0 & 73.4 & 19.0 & 15.3 & 295.3 & 186.8 & 3.35 & 2.19 \\
ton/fed & applied & & & & & & & & \\
& Zn 50 ppm & 123.0 & 85.7 & 23.0 & 16.4 & 321.3 & 212.2 & 3.49 & 2.33 \\
& Zn 100 & 128.0 & 84.7 & 26.7 & 19.1 & 357.7 & 226.3 & 3.65 & 2.49 \\
& ppm & & & & & & & & \\
\hline (2) & No Zn & 111.7 & 79.8 & 18.0 & 13.7 & 283.3 & 182.0 & 3.06 & 2.09 \\
ton/fed & applied & & & & & & & & \\
& Zn 50 ppm & 121.3 & 83.3 & 21.7 & 15.6 & 317.0 & 207.8 & 3.38 & 2.15 \\
& Zn 100 & 127.0 & 89.4 & 24.3 & 18.0 & 344.3 & 221.9 & 3.62 & 2.30 \\
& ppm & & & & & & & & \\
\hline (4) & No Zn & 116.3 & 85.4 & 21.7 & 15.9 & 303.3 & 196.2 & 3.42 & 2.34 \\
ton/fed & applied & & & & & & & & \\
& Zn 50 ppm & 125.7 & 92.1 & 24.3 & 16.4 & 331.3 & 221.1 & 3.55 & 2.40 \\
& Zn 100 & 133.3 & 94.2 & 29.7 & 20.0 & 372.7 & 237.9 & 3.77 & 2.52 \\
& ppm & & & & & & & & \\
\hline (6) & No Zn & 119.0 & 84.2 & 23.0 & 16.3 & 313.3 & 200.9 & 3.50 & 2.42 \\
ton/fed & applied & & & & & & & & \\
& Zn 50 ppm & 126.0 & 93.1 & 29.2 & 17.8 & 354.7 & 227.7 & 3.62 & 2.48 \\
& Zn 100 & 134.0 & 95.1 & 30.3 & 21.0 & 384.0 & 239.0 & 3.85 & 2.60 \\
& ppm & & & & & & & & \\
\hline LSD & Compost & 3.02 & 4.80 & 1.93 & 3.77 & 6.81 & 13.96 & 0.140 & 0.048 \\
0.05 & Zn & 2.19 & 1.27 & 1.09 & 1.39 & 5.87 & 12.33 & 0.065 & 0.039 \\
& Interaction & 4.84 & 5.34 & 2.80 & 4.79 & 11.34 & 24.40 & 0.190 & 0.081 \\
\hline
\end{tabular}


While, achieved data the lowest values with YSI were 0.69 as affected by application compost at a rate 6.0 ton fed $^{-1}$ with the foliar spray Zinc sulphate at a rate of $100 \mathrm{ppm}$ compared to control. These results are in consistent with those reported by [22] in Mungbean and [44] in maize. Nasir-ud-Din [45] showed significant and positive correlation between $Y s$ and TOL and $Y s$ and $M p$ as well as between $Y p$ and MP, while TOL was negatively correlated with $Y p$ and MP.

The SSI does not differentiate between potentially water-tolerant genotypes and those that overcome low overall yield potential. Although, low TOL has been used as a basis for selecting cultivars with fighting to water stress, the likelihood of selecting low yielding cultivars with a small yield degree of difference can be expected [46].

Data in Table 8 indicate that simple correlation among the stress tolerance indices and noticed that highly positive correlation between STI x SSI $\left(0.843^{* *}\right)$, MP $x$ STI $\left(0.999^{* *}\right)$, GMP x SSI $\left(0.842^{\star \star}\right)$, STI $\left(0.990^{\star \star}\right)$, MP $\left(1.000^{\star \star}\right)$; YI x STI $\left(0.984^{* *}\right)$, MP $\left(0.981^{* \star}\right)$, GMP $\left(0.985^{\star *}\right)$; TOL were $\left(0.955^{\star \star}\right),\left(0.962^{\star *}\right),\left(0.971^{\star *}\right),\left(0.962^{\star *}\right)$ and $\left(0.901^{* \star}\right)$ Multiply by in (SSI, STI, MP, GMP and YI, respectively. Whereas, negative significant correlation was found between YSI x SSI, STI, MP, GMP \& YI were $\left(-1,000^{* *}\right),\left(-0.843^{* *}\right),(-$ $\left.0.859^{* \star}\right),\left(-0.842^{* \star}\right) \&\left(-0.738^{* *}\right)$ and HM x YSI ($0.822^{* *}$ ). Same result was obtained by [47] for STI, MP and GMP.

Table 6. Biomass, seed yield, biological yield and harvest index of canola plant as affected by compost and zinc sulfate application

\begin{tabular}{|c|c|c|c|c|c|c|c|c|c|}
\hline \multirow[t]{2}{*}{ Compost } & \multirow[t]{2}{*}{ Zn levels } & \multicolumn{2}{|c|}{$\begin{array}{l}\text { Biomass } \\
\text { (ton fed }^{-1} \text { ) }\end{array}$} & \multicolumn{2}{|c|}{$\begin{array}{l}\text { Seed yield } \\
\text { (ton fed }^{-1} \text { ) }\end{array}$} & \multicolumn{2}{|c|}{$\begin{array}{l}\text { Biological } \\
\text { yield }(\mathrm{g})\end{array}$} & \multicolumn{2}{|c|}{$\begin{array}{c}\text { Harvest } \\
\text { index }\end{array}$} \\
\hline & & Normal & Stress & Normal & Stress & Normal & Stress & Normal & Stress \\
\hline \multirow{3}{*}{$\begin{array}{l}(0) \\
\text { ton/fed }\end{array}$} & No Zn applied & 2.81 & 1.76 & 0.94 & 0.62 & 3.75 & 2.38 & 0.25 & 0.26 \\
\hline & Zn 5 & 2.88 & 1.80 & 1.06 & 0.66 & 3.94 & 2.46 & 0.27 & 0.27 \\
\hline & $\mathrm{Zn} 1$ & 3.00 & 1.85 & 1.14 & 0.67 & 4.14 & 2.51 & 0.28 & 0.27 \\
\hline \multirow{3}{*}{$\begin{array}{l}(2) \\
\text { ton/fed }\end{array}$} & No Zn applied & 2.70 & 1.69 & 0.91 & 0.55 & 3.61 & 2.24 & 0.25 & 0.25 \\
\hline & $Z n 5$ & 2.93 & 1.73 & 0.95 & 0.59 & 3.88 & 2.31 & 0.25 & 0.25 \\
\hline & Zn 100 ppm & 2.99 & 1.78 & 0.99 & 0.61 & 3.98 & 2.39 & 0.25 & 0.25 \\
\hline & No Zn applied & 2.89 & 1.80 & 1.31 & 0.70 & 4.20 & 2.50 & 0.31 & 0.28 \\
\hline \multirow{2}{*}{ ton/fed } & Zn 50 & 3.00 & 1.86 & 1.34 & 0.72 & 4.34 & 2.58 & 0.31 & 0.28 \\
\hline & $\mathrm{ppm}$ & 3.04 & 1.91 & 1.38 & 0.74 & 4.42 & 2.64 & 0.31 & 0.28 \\
\hline & No Zn applied & 2.93 & 1.87 & 1.33 & 0.73 & 4.26 & 2.60 & 0.31 & 0.28 \\
\hline \multirow[t]{2}{*}{ ton/fed } & Zn 50 pp & 3.05 & 1.89 & 1.36 & 0.76 & 4.41 & 2.65 & 0.31 & 0.29 \\
\hline & $\mathrm{Zn}$ & 3.09 & 1.92 & 1.39 & 0.7 & 4.48 & 2.71 & 0.31 & 0.29 \\
\hline LSD & Comp & 0.036 & 0.040 & 0.005 & 0.006 & 0.038 & 0.040 & 0.269 & 0.351 \\
\hline \multirow[t]{2}{*}{0.05} & $\mathrm{Zn}$ & 0.022 & 0.012 & 0.004 & 0.005 & 0.022 & 0.012 & 0.155 & 0.171 \\
\hline & Interaction & 0.054 & 0.048 & 0.008 & 0.010 & 0.056 & 0.048 & 0.393 & 0.484 \\
\hline
\end{tabular}

Table 7. Stress tolerance indices of canola as affected by compost and zinc sulphate

\begin{tabular}{llllllllll}
\hline Varieties & Treatment & SSI & STI & MP & GMP & YI & YSI & TOL & HM \\
\hline 0 ton/fed & No Zn applied & 0.797 & 0.422 & 0.78 & 0.77 & 0.92 & 0.66 & 0.32 & 0.75 \\
& Zn 50 ppm & 0.904 & 0.502 & 0.86 & 0.84 & 0.97 & 0.62 & 0.41 & 0.81 \\
& Zn 100 ppm & 0.984 & 0.547 & 0.90 & 0.87 & 0.98 & 0.58 & 0.48 & 0.84 \\
\hline 2 ton/fed & No Zn applied & 0.935 & 0.361 & 0.73 & 0.71 & 0.81 & 0.60 & 0.36 & 0.69 \\
& Zn 50 ppm & 0.909 & 0.400 & 0.77 & 0.75 & 0.86 & 0.62 & 0.37 & 0.73 \\
& Zn 100 ppm & 0.910 & 0.433 & 0.80 & 0.78 & 0.89 & 0.61 & 0.38 & 0.75 \\
\hline 4 ton/fed & No Zn applied & 1.098 & 0.661 & 1.01 & 0.96 & 1.03 & 0.53 & 0.61 & 0.91 \\
& Zn 50 ppm & 1.099 & 0.694 & 1.03 & 0.98 & 1.06 & 0.53 & 0.63 & 0.94 \\
& Zn 100 ppm & 1.099 & 0.728 & 1.06 & 1.01 & 1.08 & 0.53 & 0.64 & 0.96 \\
\hline 6 ton/fed & No Zn applied & 1.056 & 0.702 & 1.03 & 0.99 & 1.08 & 0.55 & 0.60 & 0.95 \\
& Zn 50 ppm & 1.043 & 0.739 & 1.06 & 1.01 & 1.11 & 0.56 & 0.60 & 0.97 \\
& Zn 100 ppm & 1.031 & 0.777 & 1.08 & 1.04 & 1.15 & 0.56 & 0.61 & 1.00 \\
\hline
\end{tabular}



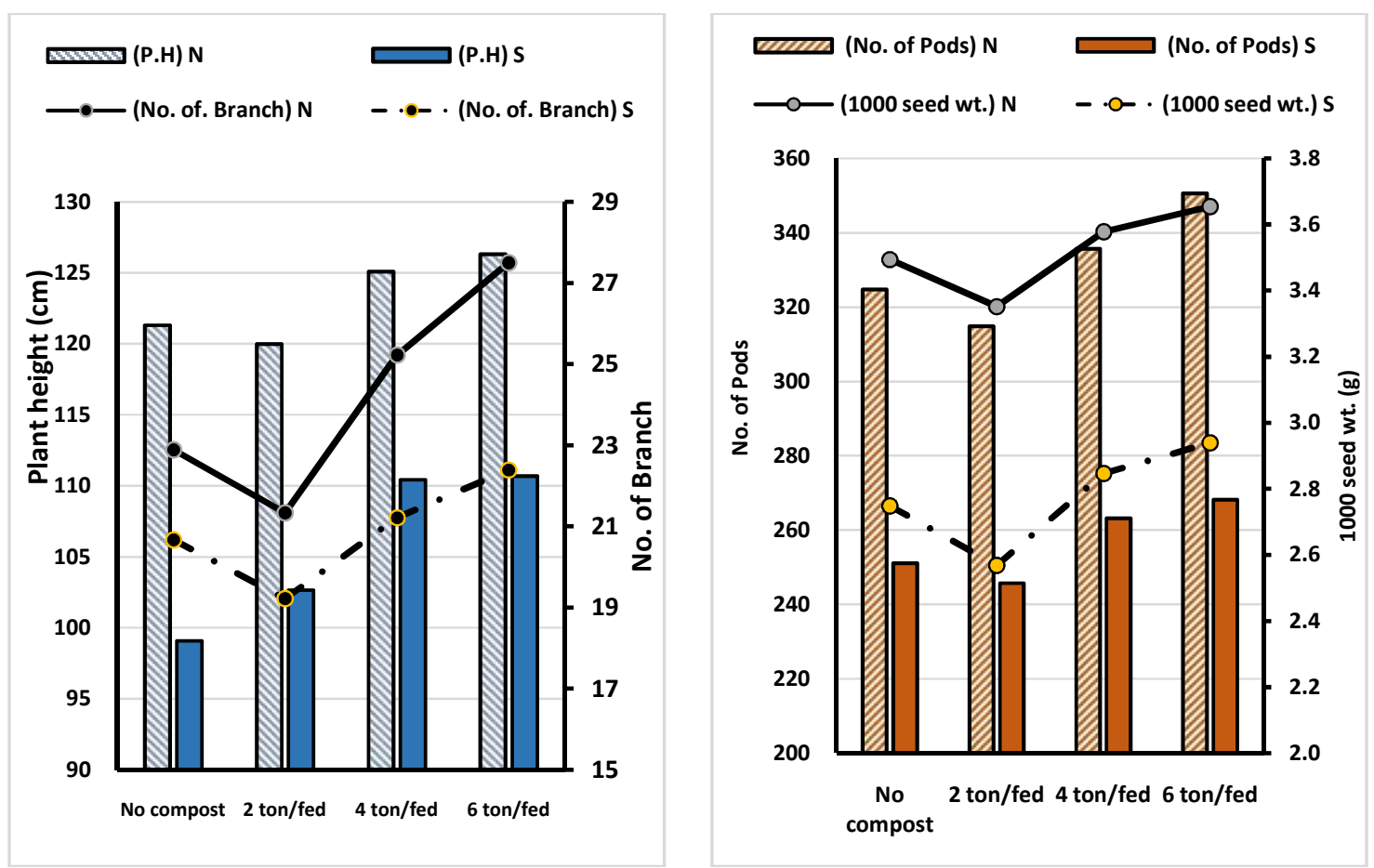

Fig. 1a. Mean effect of compost on plant height, no. of branch, no. of pods /plant and 1000 seed wt. of canola plant
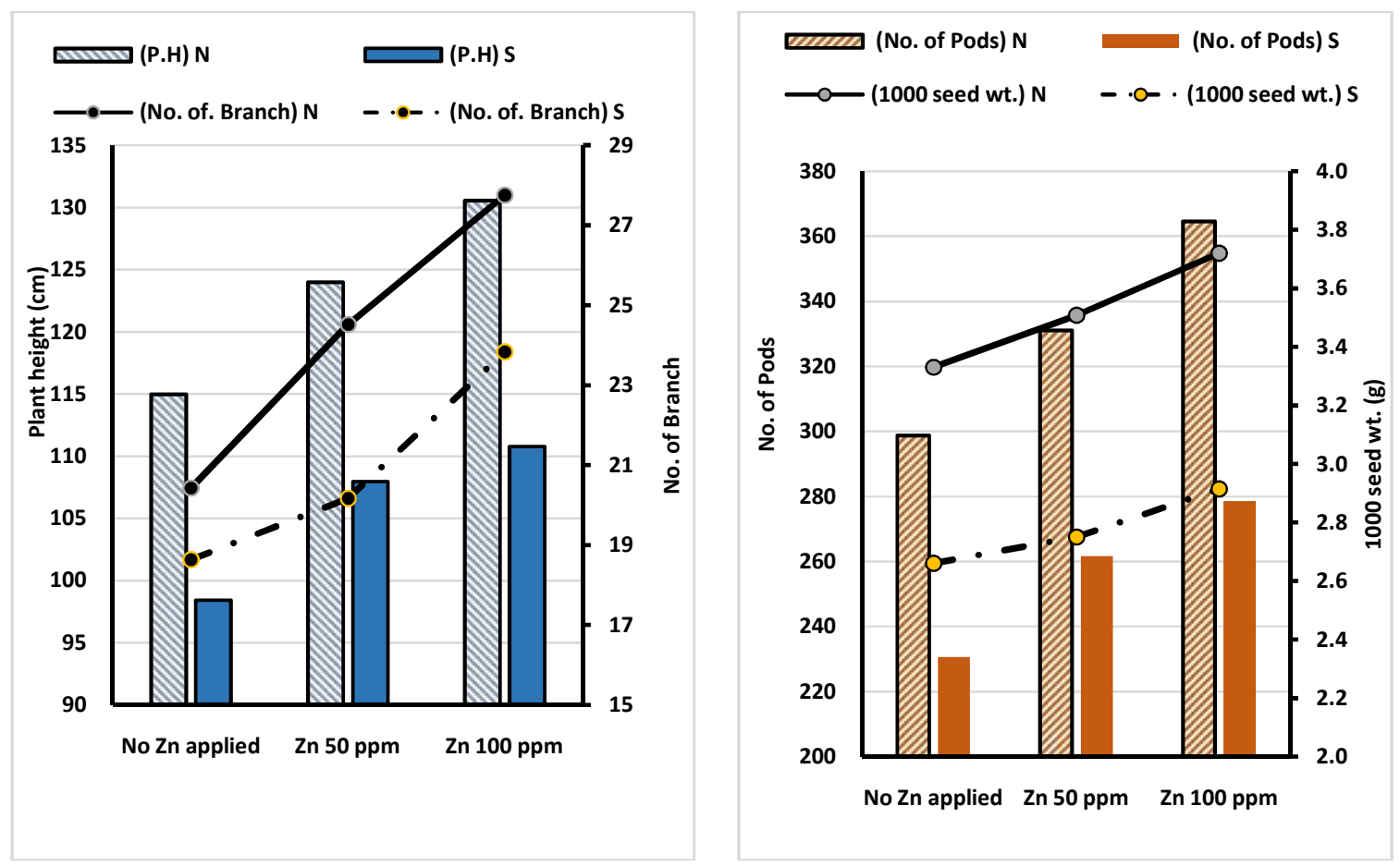

Fig. 1b. Mean effect of zinc sulfate on plant height, no. of branch, no. of pods /plant and 1000 seed wt. of canola plant 
Table 8. Correlation coefficient between stress tolerance indices of canola

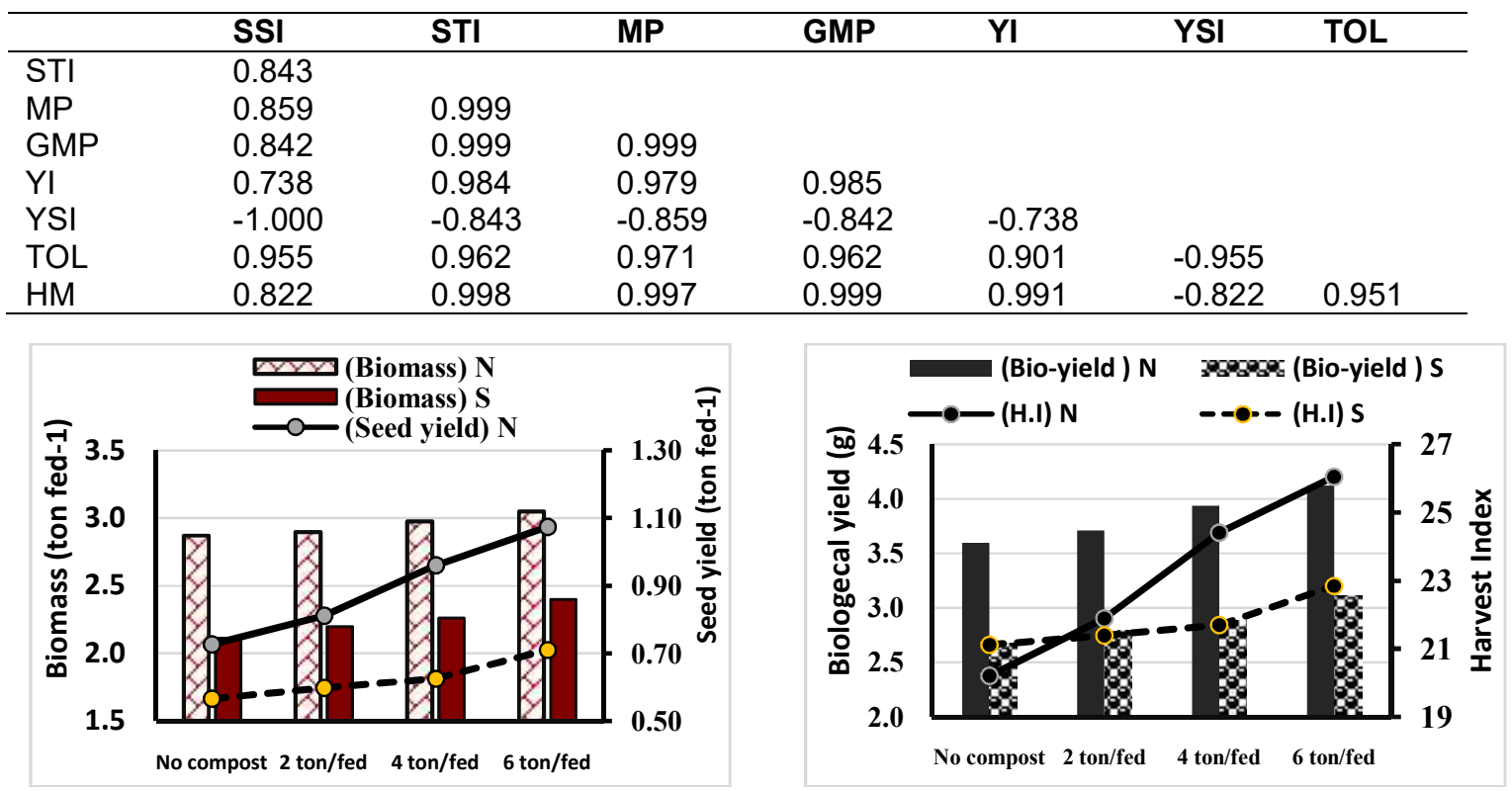

Fig. 2a. Mean effect of compost on biomass, seed yield, biological yield and harvest index of canola plant
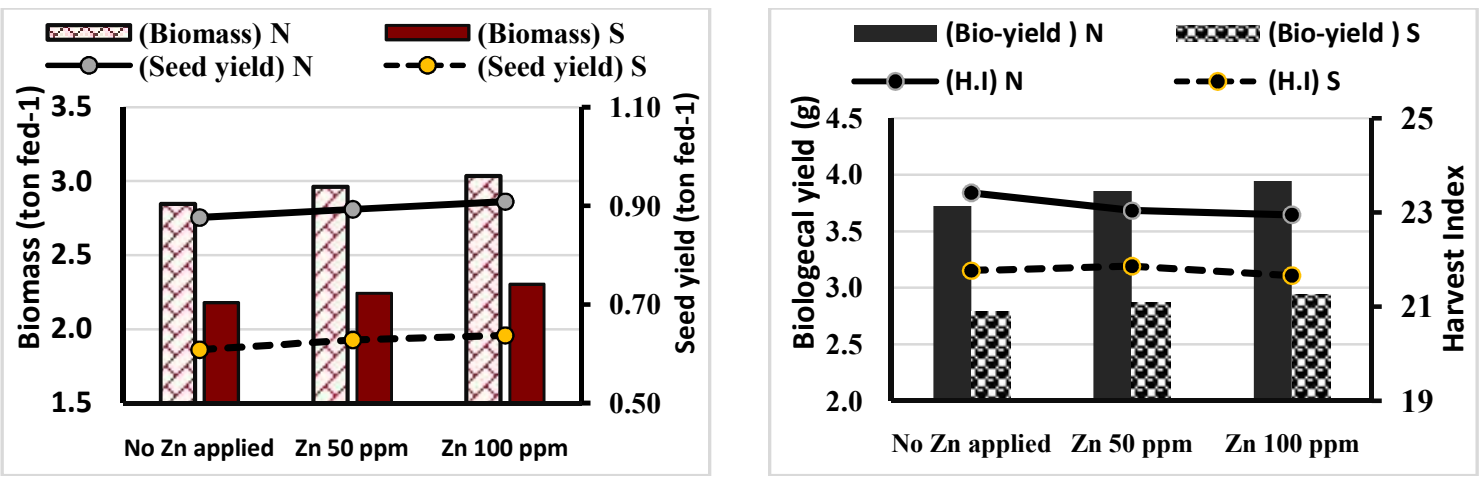

Fig. 2b. Mean effect of zinc sulfate on biomass, seed yield, biological yield and harvest index of canola plant

\section{CONCLUSION}

Soil application of organic fertilizer causes, increased water holding capacity in soil and improve itsphysical properties, besides increasing soil fertility, crop growth and thus the water use efficiency. Under water stress, zinc has an important function in the plant for enhancing $\mathrm{Zn}$ uptake by plant, which may affect the yield and $\mathrm{Zn}$ content in various plant tissues. The combined application of compost and zinc is important for enhancing the growth parameter and seed production of canola under water stress condition.

\section{ACKNOWLEDGEMENTS}

The authors warmly thank the National Research Centre (NRC), Egypt who have funded this project research work.

\section{COMPETING INTERESTS}

Authors have declared that no competing interests exist.

\section{REFERENCES}

1. FAO. Foodout look. Globalomarket analysis; 2005. 
Available: http://www.faofoodoutlook.com

2. Angadi SV, Cutforth HV. Yield adjustment by canola grown at different by plant population under semiarid condition. Crop Sci. 2003;43:1357-1366.

3. Bagheri $H$, Andalibi B, Moghaddam M, Zangani S, Soleiman S. Safflower (Carthamus tinctorius cv. Sina) oil and seed yield improvement in rain fed condition by atrazine foliar application. - Annals of Biological Research. 2012;3:1202-1209.

4. Baldini M, Givanardi R, Vanozzi GP. Effect of different water availability on fatty acid composition of the oil in standard and high oleic sunflower hybrids. - In: Proceedings of XV International Sunflower Conference, Toulouse. 2000;A79.84.

5. Amini $H$, Arzani A, Karami M. Effect of water deficiency on seed quality and physiological traits of different safflower genotypes. Turkish Journal of Biology 2014;38(2):271-282.

6. Sandeen A, Gamroth M. Composting, an alternative for livestock manure management and disposal of dead animals. EM 8825 Murch 2003. Oregon State University; 2003.

7. Karlen DM, Camp CR. Row spacing plant population, and water management effect on corn in the in the atlanta coastal plain. Agronom. J. 1985;77:393-398.

8. Mc-Callum KR, Keeling AA, Beckwith CP, Kettlewell PS.Effects of greenwaste compost on spring wheat emergence and early growth. Acta Hort. 1998;467:313-31.

9. Ramadass $\mathrm{K}$, Palaniyandi $\mathrm{S}$. Effect of enriched municipal solid waste compost application on soil available macronutrients in the rice field. Arch. Agron. Soil Sci. 2007;53:497-506.

10. Tejada M, Gonzalez J. Effects of the application $f$ a compost originating from crushed cottongin residues on wheat yield under dry land conditions. Eur. J. Agron. 2003;19:357-368.

11. Mousavi SR. Zinc in crop production and interaction with phosphorus. Aust. J. Basic \& Appl. Sci. 2011;5(9):15031509.

12. Mousavi SR, Galavi M, Ahmadvand G. Effect of zinc and manganese foliar application on yield, quality and enrichment on potato (Solanum tuberosum L.). Asian J. Plant Sci. 2007;6:1256-1260.
13. Yadavi A, Aboueshaghi RS, Dehnavi MM, Balouchi $\mathrm{H}$. Effect of micronutrients foliar application on grain qualitative characteristics and some physiological traits of bean (Phaseolus vulgaris L.) under drought stress. Indian J. Fundamental Applied Life Sci. 2014;4(4):124-131.

14. Khurana $\mathrm{N}$, Chatterjee C.Influence of variable zinc on yield: Oil content and physiology of sunflower. Soil Science and Plant Analysis. 2001;32:30233030.

15. Rebecca B. Soil survey methods manual. Soil Survey Investigations Report No. Natural Resources Conservation Services, USDA, USA; 2004.

16. Minolta. Chlorophyll meter SPAD-502. Instruction manual. Minolta Co., Ltd., Radiometric Instruments Operations, Osaka, Japan; 1989.

17. Bates LS, Waldan RP, Teare LD. Rapid determination of free proline under water stress studies. Plant Soil. 1973;39:205207. Danil AD, George CM. Peach seed dormancy in relation to endogenous inhibitors and applied growth substances. J. of Amer. Society for Hort. Sci. 1972;17: 621-624.

18. Henson IE, Mahalakshml Y., Bidinger ER, Alagarswamy G. Genotypic variation in pearlmillet (Pennisetumamericanum (L.) Leeke) in the ability to accumulate abscisic acid in response to water stress. 1. Expo Bot. 1989;32:899-910.

19. Castillo FJ. Antioxidative protection in the inducible CAM plant Sedum Album L. following the imposition of severe water stress and recovery. Oecologia. 1996;107:469- 477.

20. Fischer RA, Maurer R. Drought resistance in spring wheat cultivars. I: Grain yield response. Australian Journal of Agricultural Research. 1978;29:897-912.

21. Rosielle AA, Hambline J. Theoretical aspects of selection for yield in stress and non-stress environment. Crop Science. 1981;21:943-946.

22. Fernandez GCJ. Effective selection criteria for assessing plant stress tolerance. In: Proceeding of Symposium. Taiwan, 13-16 Aug. Chapter 25. 1992;257-270.

23. Gavuzzi P, Rizza F, Palumbo M, Campaline RG, Ricciardi GL, Borghi B. Evaluation of field and laboratory predictors of drought and heat tolerance in 
winter cereals. Canadian Journal of Plant Science. 1997;77:523-531.

24. Bouslama M, Schapaugh WT. Stress tolerance in soybean. I: Evaluation of three screening techniques for heat and drought tolerance. Crop Science. 1974;24:933937.

25. MSTAT-C, A microcomputer program for the design. Arrangement and analysis of agronomic research. Michigan State University East Lansing; 1988.

26. Snedecor GW, Cochran WG. Statistical methods. 8th Ed. lowa State Univ. Press Ames, lowa, U.S.A. 1990;609.

27. Hussain N, Hassan $G$, Arshadullah M, Mujeeb F. Evaluation of amendments for the improvement of physical properties of sodic soil. Intl. J. Agric. Bio. 2001;3:319322.

28. Babaeian M, Heidari M, Ghanbari A. Effect of water stress and foliar micronutrient application on physiological characteristics and nutrient uptake in sunflower (Helianthus annuusL). Iranian $\mathrm{J}$ of Crop Sci. 2010;12(4):311-391.

29. Monnet F, Vaillant N, Vernay P, Coudret A, Sallanon $\mathrm{H}$, Hitmi A. Relationship between PSII activity, $\mathrm{CO}_{2}$ fixation, and $\mathrm{Zn}, \mathrm{Mn}$ and Mg contents of Lolium perenne under zinc stress. Journal of Plant Physiology. 2001;158:1137-1144.

30. Tariq A, Gill Rahmatullah MA, Sabir M. Mineral nutrition of fruit trees. Proc. PlantNutrition Management for Horticultural Crops under Water-Stress Conditions, Agriculture Research Institute, Sariab, Quetta. 2004;28-33.

31. Abd El-Hady BA. Effect of zinc application on growth and nutrient uptake of barley plant irrigated with saline water. J. Appl. Sci. Res. 2007;3(6):431-436.

32. Martens DA (2000). Management and crop residue influence soil aggregate stability. J. Environ. Qual. 29: 723-727.

33. Monjezi F, Vazini F, Hassanzadehdelouei $M$. Effects of iron and zinc spray on yield and yield components of wheat (Triticumaestivum L.) in drought stress. CercetăriAgronomiceîn Moldova. 2013; XLVI(1):153.

34. Sarwar G, Hussain N, Schmeisky H Muhammad S. Use of compost and environment friendly technology for enhancing rice-wheat production in Pakistan. Pak. J. Bot. 2007;39:15531558.

35. Tafaghodinia, B, Kamalpour M. Compost tea. Sepehr (ed.) Persian,Tehran, Iran. 2008;75.

36. Agele SO, Maraiyesa IO, Adeniji IA. Effects of variety seed set efficiency in late season sunflower (Helianthus annusL.) in a humid zone of Nigeria. Academic journals. 2007;2:80-88.

37. Movahedy-Dehnavy M, Modarres- Sanavy SAM, Mokhtassi-Bidgoli A. Foliar application of zinc and manganese improves seed yield and quality of safflower (Carthamustinctorius L.) grown under water deficit stress. Industrial Crops Products. 2009;30:82-92.

38. Marcote I, Hernandez T, Garcia C, Polo A. Influence one or two successive annual application of organic fertilizers on the enzyme activity of a soil under barley cultivation. Biores. Technol. 2001;79, 147154.

39. Tu C, Ristaino JB, Hu S. Soil microbial biomass and activity in organic tomato farming systems: Effects of organic inputs and straw mulching. Soil Biol. Biochem. 20096;38:247-255.

40. Khadem SA, Galavi M, Ramrodi M, Mousavi SR, Rousta MJ, RezvaniMoghadam P. Effect of animal manure and superabsorbent polymer on corn leaf relative water content, cell membrane stability and leaf chlorophyll content under dry condition. Aus. J. Crop Sci. 2010;4(8):642-647.

41. Khan MB, Farooq M, Hussain M, Shabir G. Foliar application of micronutrients improves the wheat yield and net economic return. Int. J. Agric. Biol. 2010;12:953-956.

Welch LF. Effect of $N, P$ and $K$ and micronutrients on the percent and yield of oil in corn. Agron. J.2003;61:890891.

42. Ali Q, Ashraf M, Anwar F. Physicochemical attributes of seed oil from drought stressed sunflower (Helianthus annuus L.) plants. Grasas y Aceites. 2008;60(5):475-481.

43. Morgan P. Toilets that make compost. Stockholm Environment Institute, Stockholm, Sweden. 2007;81-90.

44. Farshadfar $E$, Afarinesh A, Sutka J. Inheritance of drought tolerance in maize. 
Cereal Research Communications. 2002; 30:285-291.

45. Nasir-ud-Din, Drager-Dayal $\mathrm{R}$, Decrind C, $\mathrm{Hu} \mathrm{BH}, \mathrm{Del}$ Giudice $\mathrm{G}$, Hoessli D. Plasmodium falciparum synthesizes O-glycosylated glycoproteins containing O-linked $\mathrm{N}$-acetylglucosamine. BiochemInt. 1992;27: 55-64.
46. Ramírez-Vallejo P, Kelly JD. Traits related to drought resistance in common bean. Euphytica. 1998;99:127136.

47. Farshadfar E, Sutka. Multivariate analysis of drought tolerance in wheat substitution lines. Cereal Research Communications. 2003;31:33-40.

(c) 2021 Sayed et al.; This is an Open Access article distributed under the terms of the Creative Commons Attribution License (http://creativecommons.org/licenses/by/4.0), which permits unrestricted use, distribution, and reproduction in any medium, provided the original work is properly cited.

Peer-review history:

The peer review history for this paper can be accessed here: http://www.sdiarticle4.com/review-history/64728 